Vol. 51, z. (1-2) - 1998

$33-41$

\title{
Some characteristics of active and latent monophenolase of mushroom polyphenol oxidase
}

\author{
JANUSZ CZAPSKI \\ Department of Storage and Processing, Research Institute of Vegetable Crops, \\ Konstytucji 3-Maja 1/3, 96-100 Skierniewice, Poland
}

(Received: December 3, 1998)

\begin{abstract}
Latent form of monophenolase of mushroom polyphenol oxidase (PPO) was activated by $0,1 \%$ sodium dodecyl sulfate (SDS). The addition of increasing concentrations of 4-methylcatechol diminished lag period of active and total monophenolase activity, measured using p-cresol with L-proline as a substrate. Changes of lag period were described by equation of one phase exponential decay when concentration of substrate varied from 1 to $10 \mathrm{mM}$. Affinity $\left(1 / \mathrm{K}_{\mathrm{m}}\right)$ toward substrate of latent monophenolase was over two times higher than that of the active form, while the maximum velocity $\left(\mathrm{V}_{\max }\right)$ was two times lower. The catalytic power $\left(\mathrm{V}_{\max } / \mathrm{K}_{\mathrm{m}}\right)$ of both forms of monophenolase were almost equal. Electrophoretic analysis followed by scanning technique of the gels was used. Absorbancy of spots, determined from computer image of isoenzyme bands pattern allowed for qualitative and quantitative estimation of electrophoregrams. Presence of one additional clearly defined slow migrating isoenzyme for SDS activated monophenolase differed in this respect active ( 2 bands) and total ( 3 bands) forms of monophenolase.

Key words: Agaricus bisporus; mushroom; latent and active monophenolase; lag period; enzyme kinetic; electrophoretic isoenzyme pattern.
\end{abstract}

\section{INTRODUCTION}

The active site of polyphenol oxidase (PPO, EC. 1.14.18.1) consists of two copper atoms in three states: ,,met" $\left(\mathrm{Cu}^{+2} \mathrm{Cu}^{+2}\right)$, , deoxy” $\left(\mathrm{Cu}^{+} \mathrm{Cu}^{+}\right)$and ,oxy” $\left(\mathrm{Cu}^{+2}-\mathrm{O}_{2}{ }^{-2}-\mathrm{Cu}^{+2}\right)$ (Lerch, 1981; Espin et al., 1998). The presence of three copper states in the active site of PPO has led to a structural model being proposed for the reaction mechanism involved in the hydroxylation of monophenols and oxidation of the o-diphenols (Solom on et al., 1996). In many crude extracts of polyphenol oxidase (PPO) from fruits and vegetables, the monophenolase activity is very low. The kinetic characterization is usually carried out under conditions where the coupling reaction between nucleophiles and the quinones (products of the oxidation of monophenols and 
o-diphenols) is significant. When monophenolase acts on p-cresol the 4-methyl-o-benzoquinone initially formed is reduced to 4-methylcatechol by the adducts formed between the quinone and a nucleophile such as proline (Vale ro et al., 1988). L-Proline does not modify the kinetic parameters of catecholase activity but modifies maximum velocity $\left(\mathrm{V}_{\max }\right)$ of cresolase activity and affects the lag period and the steady state rate of this activity (Garcia-Carmona et al., 1988). Most of the described methods are focused on the diphenolase activity of PPO. However, there are only a few works on monophenolase activity, because the enzymes' kinetic mechanism of action on monophenols has only been recently clarified (Rodriguez-Lopez et al., 1992; Ros et al., 1994).

Apple and avocado polyphenol oxidase isolated and partially purified using Triton X-114 showed both monophenolase and diphenolase activities (Espin et al., 1995, 1997a). Monophenolase from both sources showed that the lag period and steady state rate depended on the $\mathrm{pH}$, enzyme and substrate concentrations, and the presence of catalytic amounts of o-diphenol. Recently Espin et al. (1997b) developed an improved continuous spectrophotometric method to determine the monophenolase and diphenolase activities of mushroom PPO, useful for estimation of micro quantities of PPO in problem samples. Since information concerning latent mushroom monophenolase is very limited this study was undertaken to compare activity, kinetic parameters and electrophoretic pattern of active and latent forms of monophenolase of mushroom PPO using p-cresol as a substrate and L-proline as coupling agent. Proline has been found in large quantities in mushrooms and it can react with enzymatically produced quinones to form pigments largely responsible for the color of mushrooms (Jackson, Kendal, 1949).

\section{MATERIALS AND METHODS}

Fresh mushrooms (Agaricus bisporus) white strain $\mathrm{H}-25$ at streched veil were obtained from Mushroom Experimental Facility of Research Institute of Vegetable Crops. After triming the stipe they were taken immediately for enzyme preparation. Commercial mushroom tyrosinase (activity 3,400 Units/mg solid) was purchased from Sigma. All reagents were the best commercial grade available and were used without further purification.

Acetone powder was prepared using $100 \mathrm{~g}$ tissue of mushroom portion and 5 parts of cold acetone according to the method described before for apples ( $\mathrm{Cz}$ a p s k i et al.,1988). Total (T) polyphenol oxidase containing latent (L) and active (A) monophenolase was extracted using the method of Yamaguchi et al. (1970) for o-diphenolase. Unless otherwise indicated $100 \mathrm{mg}$ of acetone powder, equivalent of $1,8 \mathrm{~g}$ fresh weight (f.wt.) was suspended in $10 \mathrm{ml}$ of cold $0,1 \mathrm{M}$ phosphate buffer $\mathrm{pH}$ 6,5 , containing $0,1 \%$ sodium dodecyl sulfate (SDS). Active PPO sample was prepared similarly, except that the buffer solution contained no SDS. The suspensions were mixed periodically over a $5 \mathrm{~min}$ period then they were centrifuged at $12000 \times \mathrm{g}$ at $2 \mathrm{C}$ for $15 \mathrm{~min}$. The supernatant fluid containing monophenolase was decanted into test tube for use. 
Enzymatic activity was measured by determining amount of adduct formed between 4-methyl-o-benzoquinone and L-proline as a nucleophilic agent. The continuous spectrophotometric method was employed for assaying monophenolase activity of PPO using Spectromon 195D spectrophotometer equipped with Kipp and Zonen micrograph BD5. The enzymatic activity was determined at $525 \mathrm{~nm}$ and at $25^{\circ} \mathrm{C} \pm 0,1^{\circ} \mathrm{C}$. Unless otherwise indicated the reaction mixture contained $10 \mathrm{mM}$ p-cresol, $10 \mathrm{mM}$ $\mathrm{L}$-proline and $1,93 \times 10^{5} \mathrm{M}$ 4-methylcatechol in $0,1 \mathrm{M}$ phosphate buffer $\mathrm{pH} 6,5$; the final volume was $3 \mathrm{ml}$. For routine work, the cuvettes contained 2,8 and $2,9 \mathrm{ml}$ of reaction mixture and 0,2 and $0,1 \mathrm{ml}$ enzyme extract respectively. The blank sample contained $3 \mathrm{ml}$ substrate solution. For study effect of o-diphenol, different concentrations of 4-methylcatechol were used and lag period and activity of monophenolase was determined. Enzyme activity was calculated from the linear portion of the curve and recorded the change in absorbance. Enzyme activity was expressed as micro mol p-cresol oxidized per minute per 1 gram fresh weight $\left[\mu \mathrm{mol} \times(\min \times \mathrm{g})^{-1} \mathrm{f}\right.$. wt. $]$. Latent (L) activity of monophenolase was calculated from total (T) minus active (A) activity: L=T-A. Value of molar absorptivity $\varepsilon=1,36 \times 10^{3} \mathrm{M}^{-1} \times \mathrm{cm}^{-1}$ of 4-methyl-o-benzoquinone-L-proline pigment was determined at $525 \mathrm{~nm}$ by fast oxidation of p-cresol $(0,5 \mathrm{mM})$ with $1 \mathrm{mM} \mathrm{L}$-proline by commercial tyrosinase in presence of $1,93 \times 10^{-5} \mathrm{M}$ 4-methylcatechol. This molar absorptivity value is similar to that of $1,23 \times 10^{3}$ obtained by Long and Alben (1968) measured at $400 \mathrm{~nm}$. It differs somewhat from the value of $10^{2}$ measured at $377 \mathrm{~nm}$ which is wavelength of the isosbestic point and obtained when 4-methylcatechol was oxidized with an excess of sodium periodate in the presence of L-proline (Garcia-Carmon a et al., 1988).

Michaelis constant $\left(\mathrm{K}_{\mathrm{m}}\right)$ and maximum velocity $\left(\mathrm{V}_{\max }\right)$ was determined using the substrate in various concentrations. Data were plotted according to the method of Lineweaver and Burk (1934) and used linear regression fitting of GraphPad Prism program for Windows.

The multiple enzyme forms of active and total monophenolase were separated in 7,5\% polyacrylamide gel, using disc technique of Orstein and Davies ( $\mathrm{S}$ a rg e n t, 1969). Samples for electrophoresis of active and total monophenolase were prepared by the extraction of enzyme from acetone powder as described above. Sample was introduced together with upper gel before polymerization. Enzyme activities introduced with upper gel were: $\mathrm{A}=79 \mathrm{nmol} \times \min ^{-1} ; \mathrm{T}=172 \mathrm{nmol} \times \min ^{-1}$. The electrode buffer was $0,05 \mathrm{M}$ Tris - $0,38 \mathrm{M}$ glycine, $\mathrm{pH} 8,3$. Bromophenol blue $(0,001 \%)$ was added as the tracking dye. The electrophoresis was runing at $2{ }^{\circ} \mathrm{C}$ and $2 \mathrm{~mA}$ per tube was applied until the bromophenol blue had reached the ,running" gel, then current was increased to $4 \mathrm{~mA}$. Immediately after stopping the electrophoretic run the gels were removed from the tubes and incubated in $0,1 \mathrm{M}$ phosphate buffer $\mathrm{pH} 6,5$ for $30 \mathrm{~min}$ and then stained with substrate solution containing $10 \mathrm{mM}$ p-cresol, $10 \mathrm{mM}$ L-proline and 1,93 $\times 10^{5} \mathrm{M} 4$-methylcatechol in $0,1 \mathrm{M}$ phosphate buffer $\mathrm{pH} 6,5$ until bands showing monophenolase activity were evident. Then the gels were rinsed with water and placed in deionized water and scanned as soon as possible.

The ScanMan hand held scanner and Logitech ScanMan Software was used as an image source for the FotoTouch Image Editing Software. The computer image of stained gels was then printed using Hewlett-Packard LaserJet 5P printer. 
Computer image of isoenzyme bands on gel, printed on paper occurred in the shape of spots pattern. Spot area and absorbance was determined using Universal Densitometer Vitatron. The instrument provides the possibility of carrying out quantitative determinations of spots on TLC plates by means of transmitted light measurement. Instead of TLC plate sheet of paper with printed computer image of spots pattern was used. Each spot was scanned in a zig-zag sine wave pattern and the photomultiplier measured the light intensity ( I) continuously. The log I values were summed and the average value was passed continuously to the recorder and integrator.

\section{RESULTS AND DISCUSSION}

It is known that monophenolase has a lag period before expressing its activity (Garcia-Carmona et al., 1988). The addition of increasing concentrations of 4-methylcatechol diminished the lag period (Fig. 1). 4-Methylcatechol was tried as cofactor because it is produced by reduction of p-methyl-o-quinone from p-cresol oxidation. Without 4-methylcatechol addition no detectable oxidation of p-cresol by active and total monophenolase occurred within 116 and 30 seconds period respectively. Rise in the initial 4-methylcatechol concentration shortened the lag period. The concentration of 4-methylcatechol chosen for the assay procedure was $0,0193 \mathrm{mM}$ (Fig. 1) because if it was simultaneously oxidized to p-methyl-o-quinone by the diphenolase reaction, it would result in activity change too small to be detected. G a r cia Carmona et al. (1988) reported that the lag period of cresolase activity was eliminated at a concentration of $0,02 \mathrm{mM}$ of 4-methylcatechol in the presence of $4 \mathrm{mM}$ L-proline. When the initial 4-methylcatechol concentration is higher than that in the steady state, the enzyme must first consume excess of this o-diphenol and then gradually consume the p-cresol and o-diphenol before the steady state rate is finally reached. This explains a burst in the activity at $0,029 \mathrm{mM}$ of 4 -methylcatechol (Fig. 1).

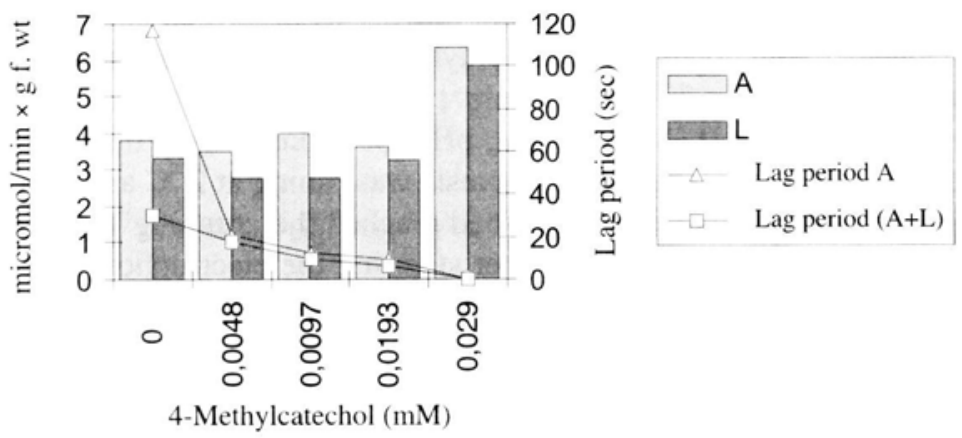

Fig. 1. Effect of catalytic amounts of 4-methylcatechol on the steady state activity of active (A) and latent $(\mathrm{L})$ monophenolase and on the lag period of active and total $(\mathrm{A}+\mathrm{L})$ monophenolase 
The effect on lag period by varying concentration of substrate $(1-10 \mathrm{mM})$ and at constant concentration 0,0193 mM of 4-methylcatechol is shown in Figure 2. Analysis of curves with nonlinear regression showed that both of them are described by equation of one phase exponential decay: $y=a \cdot \exp (-k \cdot x)+b$ (Fig. 2). In experiment with commercial mushroom tyrosinase, presence of $1 \mathrm{mM} \mathrm{L}$-proline in reaction mixture without 4-methylcatechol, decreased lag period by $42 \%$, without changing its activity (data not shown here).

Immediately after extraction, participation of active and latent forms of monophenolase in total activity was $64 \%$ and $36 \%$ respectively. After 1 day of storage activity of latent monophenolase increased sharply being 2,5 times higher than its initial value and then it reached a steady level remaining constant up to 18 days. Active monophenolase activity increased significantly after 1 day (1,4 times than its initial value) and did not change during the further 18 days of storage. Participation of active and latent monophenolase in total activity after 1 day of storage was about $50 \%$ respectively.

Study of the effect of different concentrations of SDS added to extraction buffer was measured after 1 day of storage (Tab. 1). SDS produced stable activation of latent form of monophenolase

The results given in double reciprocal plots lead to parallel lines for active and latent forms of monophenolase (Fig. 3). These imply that there are different kinetic parameters for both forms of monophenolase. Values of kinetic parameters, Michaelis constant $\left(\mathrm{K}_{\mathrm{m}}\right)$ and maximum velocity $\left(\mathrm{V}_{\mathrm{max}}\right)$ calculated from the equation of Lineweaver Burk plots (Fig. 3) are summarized in Table 2. The speed of catalytic action which was directly related to $\mathrm{V}_{\max }$ values was very dependent on form of monophenolase present (active or latent). Maximum velocity of activated latent form was about two times lower than that of active one, however the affinity which is directly related to $1 / \mathrm{K}_{\mathrm{m}}$ values is over two times higher than that of active one. The catalytic power $\left(\mathrm{V}_{\max } / \mathrm{K}_{\mathrm{m}}\right)$ of both forms of monophenolase is almost equal. In many crude extracts of PPO from fruits and vegetables the monophenolase activity is very low, so losses in the PPO activity lead to a very low catalytic power for the monophenolase activity (Walter, Pu rcell, 1980; Khan, Pomerantz, 1980; Mayer, Harel, 1979; Matheis, 1987). In this respect the differences seen in monophenolase activity may be due to the methods of extraction and assaying which can protect the catalytic properties to a greater or lesser extent.

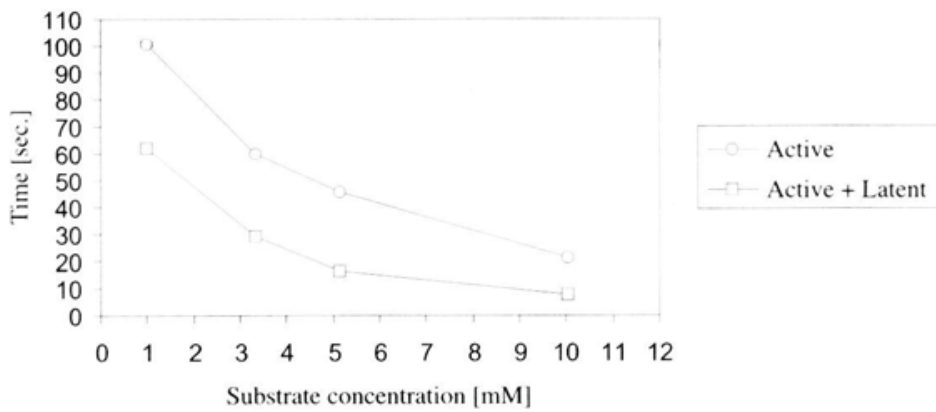

Fig. 2. Effect of substrate concentration on the lag period of active (A) and total (A+L) monophenolase activity. Reaction mixture contained 1,93 ( $10^{\mathrm{M}} \mathrm{M}$ 4-methylcatechol as cofactor. The equations of regression curves of $\mathrm{A}$ and $(\mathrm{A}+\mathrm{L})$ are as follows: $y(A)=78 \cdot \exp (-0,182 \cdot x)+23 ; y(A+L)=54 \cdot \exp \cdot-0,182 \cdot x)+8$ 


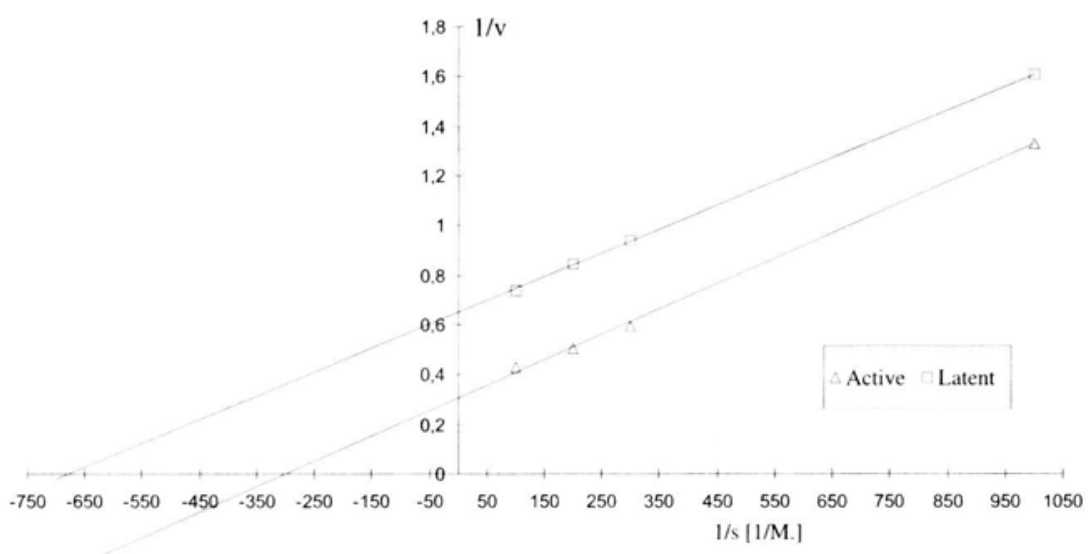

Fig. 3. Linweaver - Burk double reciprocal plots of the p-cresol with L-proline concentrations (s) versus reaction velocity $(\mathrm{v}) \mid \mu \mathrm{mol} \cdot(\mathrm{min} \cdot \mathrm{g})^{-1}$ f.wt. $\mid$ of active $(\mathrm{A})$ and latent $(\mathrm{L})$ monophenolase of mushroom PPO.

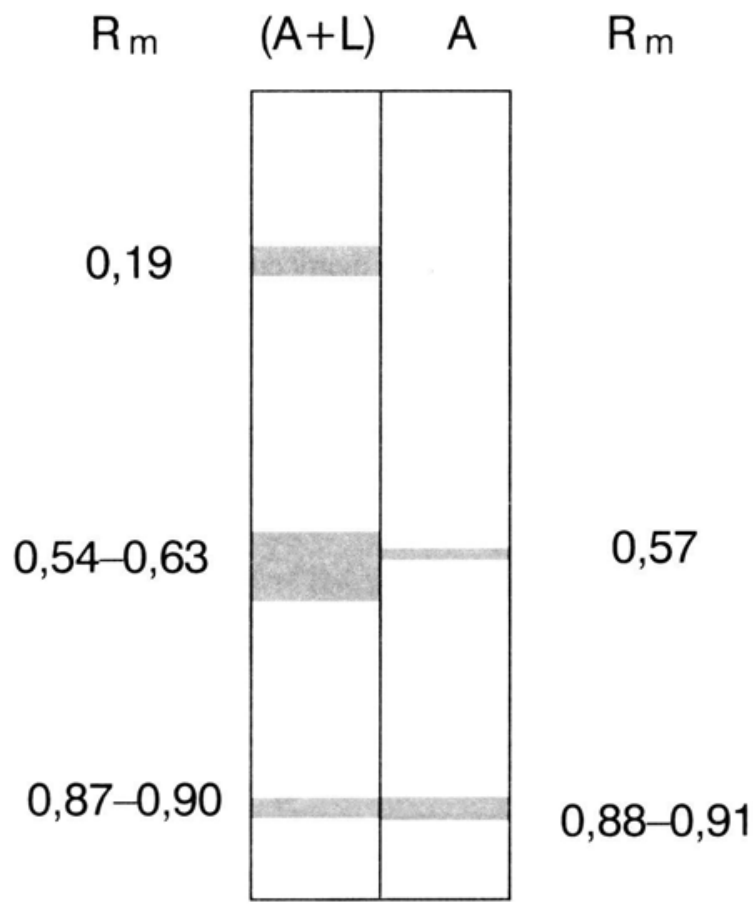

Fig. 4. Electrophoretic isoenzyme pattern of active (A) and total $(A+L)$ mushroom monophenolase. All comparisons between electrophoregrams were normalized to $R_{m}$ among 0 and 1 . 
Electrophoretic analysis of active and total monophenolase of mushroom PPO revealed two main isoenzymes for active $\left(\mathrm{R}_{\mathrm{m}}: 0,57 ; 0,88-0,91\right)$ and three broad zone bands $\left(\mathrm{R}_{\mathrm{m}}: 0,19 ; 0,54-0,63 ; 0,87-0,90\right)$ for total one (Fig. 4).

All bands of active monophenolase have analogues in total one. Presence of one clearly defined slowly moving isoform at $\mathrm{R}_{\mathrm{m}}=0,19$ for SDS activated monophenolase differ in this respect for active and total monophenolase. The pattern of both forms of monophenolase showed charecteristic tailed bands. Since different initial activities of active and total monophenolase were electrophoretically analyzed, relative intensity of individual spot as percentage of all spots intensity was calculated and presented in Table 3.

Table 1

Effect of sodium dodecyl sulfate (SDS) content in extraction buffer on activation of latent (L) monophenolase from mushroom acetone powder $\left[\mu \mathrm{mol} \times(\mathrm{min} \times \mathrm{g})^{-1}\right.$ f.wt. $]$

\begin{tabular}{|c|c|}
\hline SDS content $(\%)$ & Activity (L) \\
\hline $0^{*}$ & 4,76 \\
0,05 & 5,04 \\
0,1 & 5,11 \\
0,3 & 5,19 \\
\hline
\end{tabular}

* Active monophenolase

Table 2

Kinetic parameters of active and latent monophenolase for p-cresol with L-proline substrate

\begin{tabular}{|c|c|c|c|}
\hline Monophenolase & $\mathrm{K}_{\mathrm{m}}(\mathrm{mM})$ & $\mathrm{V}_{\max }\left[\mu \mathrm{mol} \times(\min \times \mathrm{g})^{-1}\right.$ f.wt. $]$ & $\mathrm{V}_{\max } \cdot \mathrm{K}_{\mathrm{m}}^{-1}\left(\min ^{-1}\right)$ \\
\hline Active & $3,32 \pm 0,07$ & $3,26 \pm 0,11$ & 0,98 \\
Latent & $1,49 \pm 0,012$ & $1,55 \pm 0,01$ & 1,04 \\
\hline
\end{tabular}

Table 3

Relative intensity of individual spot as percentage of sum all spots intensity after electrophoretic analysis of active (A) and total $(\mathrm{A}+\mathrm{L})$ mushroom monophenolase

\begin{tabular}{|c|cc|cc|}
\hline \multirow{2}{*}{ No. of spot } & \multicolumn{2}{|c|}{ Active (A) } & \multicolumn{2}{c|}{ Total (A+ L) } \\
\cline { 2 - 5 } & $\mathrm{R}_{\mathrm{m}}{ }^{*}$ & $\begin{array}{c}\text { Relative intensity } \\
(\%)^{* *}\end{array}$ & $\mathrm{R}_{\mathrm{m}}{ }^{*}$ & $\begin{array}{c}\text { Relative intensity } \\
(\%)^{* * *}\end{array}$ \\
\hline 1 & & - & 0,19 & $44,5 \pm 2,1$ \\
2 & 0,57 & $61,3 \pm 2,5$ & $0,54-0,68$ & $38,1 \pm 1,4$ \\
3 & $0,88-0,95$ & $38,7 \pm 1,7$ & $0,87-0,90$ & $17,4 \pm 0,7$ \\
\hline
\end{tabular}

* Relative mobility (see Fig. 4)

** Mean \pm SE of the mean

The distributions of relative intensity of spots for active monophenolase differ significantly from the total one. Spot at $R_{m}=0,19$ has highest relative intensity of total monophenolase. This fraction is absent in active monophenolase and it might be a latent form after SDS activation, however one can not rule out also the possibility that SDS induces specific conformational changes in the protein complexes or it could 
dissociate proteins into subunit(s) electrophoretically active fraction at $R_{m}=0,19$. It is worth mentioning that $0,1 \%$ SDS had no effect on monophenolase isoenzymes pattern of commercial tyrosinase showing (with or without SDS) only one broad spot at $R_{m}=0,73-0,87$ (data not shown here). This does not correspond with any isoenzyme band presented here and might be the result of differences of the enzyme preparation and/or purification.

\section{REFERENCES}

Czapski J., Saniewski M., Puchalski J., Lange E., Nowacki J., 1988. The effect of methyl jasmonate on activity and electrophoretic pattern of polyphenol oxidase in postclimacteric apples $\mathrm{cv}$. Jonathan. Fruit Sci. Reports 15: 103-110.

Espin J.C.. Morales M.. Varon R.. Tudela J.. Garcia-Canovas F.. 1995. Monophenolase activity of polyphenol oxidase from Verdedoncella apple. J. Agric. Food Chem. 43: 2807-2812.

Espin J.C.. Trujano F.. Garcia-Canovas F.. 1997a. Monophenolase activity of polyphenol oxidase from Haas avocado. J. Agric. Food Chem. 45: 1091-1096.

Espin J.C.. Morales M.. Garcia-Ruiz P.A.. Tudela J., Garcia-Canovas F.. 19976. Improvement of continuous spectrophotometric method for determining the monophenolase and diphenolase activities of mushroom polyphenol oxidase. J. Agric. Food Chem. 45: 1084-1090.

Espin J.C., Garcia-Ruiz P.A., Tudela J., Varon R., Garcia-Canovas F., 1998. Monophenolase and diphenolase reaction mechanisms of apple and pear polyphenol oxidase. J. Agric. Food Chem. 46: 2968-2975.

Garcia-Carmona F.. Valero E.. Cabanes J.. 1988. Effect of L-proline on mushroom tyrosinase. Phytochemistry 27: 1961-1964.

Jackson H.. Kendal L.P. 1949. The oxidation of catechol and homocatechol by tyrosinase in the presence of amino acids. Biochem. J. 44: 477-487.

Khan V.. Pomerantz S.H.. 1980. Monophenolase activity of avocado polyphenol oxidase. Phytochemistry 19: 379-385.

Lerch K., 1981. Copper monooxygenases: tyrosinase and dopamine $\beta$-monooxygenase. [In:] Metal ions in biological systems. H. Siegel (ed.), Marcel Dekker, New York v.13 pp.143-186.

Lineweaver H.. Burk D.. 1934. The determination of enzyme dissociation constants. J. Am. Chem. Soc. 56: 685-693.

Long T.J.. Alben J.O.. 1968. Preliminary studies of mushroom tyrosinase (polyphenol oxidase) Mushroom Sci. 7: 67-79.

Matheis G.. 1987. Polyphenol oxidase and enzymatic browning of potatoes (Solanum tuberosum). I. Properties of potato polyphenol oxidase. Chem. Microbiol. Technol. Lebensm. 11: 5-12.

Mayer A.M.. Harel E.. 1979. Polyphenol oxidase in plants. Phytochemistry 18: 193-215.

Rodriguez-Lopez J.N., Tudela J., Varon R., Garcia-Carmona F., Garcia-Canovas F.. 1992. Analysis of a kinetic model for melanin biosynthesis pathway. J. Biol. Chem. 267: 3801-3810.

Ros J.R.. Rodriguez-Lopez J.N.. Garcia-Canovas F., 1994. Tyrosinase: kinetic analysis of the transient phase and the steady state. Biochim. Biophys. Acta 1204: 33-42.

Sargent J.R.. 1969. Methods in zone electrophoresis. BDH Chemical Ltd.. pp. 85-107.

Solomon E.I.. Sundaram U.M.. Machonkin T.E.. 1996. Multicopper oxidases and oxygenases. Chem. Rev, 96: 2563-2605.

Valero F.. Escribano J.. Garcia-Carmona F., 1988. Reactions of 4-methyl-o-benzoquinone. generated chemically and enzymatically in the presence of L-proline. Phytochemistry 27: 2055-2061.

Walter W.M.J.. Purcell A.E., 1980. Effect of substrate levels and polyphenol oxidase activity on darkening in sweet potato cultivars. J. Agric. Food Chem. 28: 941-944.

Yamaguchi M., Hwang P.M., Campbell J.D., 1970. Latent o-diphenolase oxidase in mushrooms (Agaricus bisporus). Can. J. Biochem. 48: 198-202. 


\section{Niektóre własności aktywnej i utajonej monofenolazy oksydazy polifenolowej grzybów}

\section{Streszczenie}

Utajoną formę monofenolazy pieczarek (Agaricus bisporus) aktywowano $0,1 \%$ roztworem siarczanu dodecylo-sodowego (SDS). Dodanie wzrastających ilości 4-metylokatecholu obniżało opóźnienie czsowe tzw. ,lag period" reakcji enzymatycznej całkowitej (aktywna + utajona) i aktywnej formy monofenolazy, dla substratu p-krezol-l-prolina. Zmiany,,lag periodu" opisano równaniem wykładniczym w zakresie stężeń substratu 1-10 mM. Powinowactwo do substratu utajonej formy monofenolazy było ponad dwukrotnie większe niż aktywnej, natomiast szybkość maksymalna $\left(\mathrm{V}_{\max }\right)$ była dwukrotnie mniejsza. Siła katalityczna $\left(V_{\max } / K_{m}\right)$ obydwu form monofenolazy była prawie jednakowa. Rozdział elektroforetyczny i następnie „skaningowanie” żeli pozwoliło na uzyskanie obrazu komputerowego wzoru izoenzymatycznego oraz na jego ilościową ocenę. Obecność jednego dodatkowego izoenzymu we wzorze izozymowym obydwu form aktywnej i utajonej łącznie ( 3 frakcje), odróżniało go od wzoru izozymowego tylko formy aktywnej ( 2 frakcje). 